CONF- 830451-23

DP-MS-83-66

\title{
PRELIMINARY REPORT ON A GLASS BURIAL EXPERIMENT IN GRANITE
}

by

D. E. Clark. B. F. Zhu, and R. S. Robinson

Department of Materials Science and Engineering

University of Florida

Gainesville, Florida 32611

\section{G. G. Wicks}

E. I. du Pont de Nemours \& Co.

Savannah River Laboratory

Aiken, SC 29808

DP-MS- $-83-66$

DE83 017426

Proposed for presentation at the American

Ceramic Society leeting in Chicago, Illinois

on April 24-27, 1983 and for publication

in the proceedings

\section{DISCLAIMER}

This report was prepared as an account of work sponsored by an agency of the United States Government. Neither the United States Government nor any agency thereof, nor any of their employees, makes any warranty, express or implied, or assumes any legal liability or responsibility for the accuracy, completeness, or usefulness of any information, apparatus, product, or process disclosed, or represents that its use would not infringe privately owned rights. Reference herein to any specific commercial product, process, or service by trade name, trademark, manufacturer, or otherwise does not necessarily constitute or imply its endorsement, recommendation, or favoring by the United States Government or any agency thereof. The views and opinions of authors expressed herein do not necessarily state or reflect those of the United States Government or any agency thereof.

This paper was prepared in connection with work done under Contract No. DE-AC09-76SR00001 with the U.S. Department of Energy. By acceptance of this paper, the publisher and/or recipient acknowledges the U.S. Government's right to retain a nonexclusive, royalty-free license in and to any copyright covering this paper, along with the right to reproduce and to authorize others to reproduce all or part of the copyrighted paper. 


\section{DISCLAIMER}

This report was prepared as an account of work sponsored by an agency of the United States Government. Neither the United States Government nor any agency Thereof, nor any of their employees, makes any warranty, express or implied, or assumes any legal liability or responsibility for the accuracy, completeness, or usefulness of any information, apparatus, product, or process disclosed, or represents that its use would not infringe privately owned rights. Reference herein to any specific commercial product, process, or service by trade name, trademark, manufacturer, or otherwise does not necessarily constitute or imply its endorsement, recommendation, or favoring by the United States Government or any agency thereof. The views and opinions of authors expressed herein do not necessarily state or reflect those of the United States Government or any agency thereof. 


\section{DISCLAIMER}

Portions of this document may be illegible in electronic image products. Images are produced from the best available original document. 
DP-MS-83-66

\section{PRELIMINARY REPORT ON A GLASS BURIAL EXPERIMENT IN GRANITE}

by

D. E. Clark. B. F. Zhu, and R. S. Robinson

Department of Materials Science and Engineering

University of Florida

Gainesville, Florida 32611

G. G. Wicks

E. I. du Pont de Nemours \& Co.

Savannah River Laboratory

Aiken, SC 29808

\section{ABSTRACT}

Preliminary results of a two-year burial experiment in granite are discussed. Three compositions of simulated alkali borosilicate waste glasses were placed in boreholes approximately 350 meters deep. The glass sample configurations include mini-cans (stainless steel rings into which glass has been cast) and pineapple slices (thin sections from cylindrical blocks). Assemblies of these glass samples were prepared by stacking them together with granite, compacted bentonite and metal rings to provide several types of interfaces that are expected to occur in the repository. The assemblies were maintained at cither ambient inine temperature $\left(8\right.$ to $\left.10^{\circ} \mathrm{C}\right)$ or $90^{\circ} \mathrm{C}$. The glasses were analyzed before burial and after one month storage at $90^{\circ} \mathrm{C}$. The most extensive surface degradation occurred on the glasses interfaced with bentonite. In general, very little attack was observed on glass surfaces in contact with the other materials. The limited field and laboratory data are compared.

* The information contained in this article was developed during the course of work under Contract No. DE-AC09-76SR00001 with the U.S. Department of Energy. 


\section{INTRODUCTION}

Many laboratory tests of simulated high level wastes (HLW) in vitrified glass matrices have been conducted in the U.S. HLW program. However, very little data are available on the corrosion behavior of such waste forms buried in deep boreholes in rock formations potentially suitable for long-term geologic isolation.

The Swedish program for evaluation includes burial of simulated waste forms in the granite of the Stripa mine. The Stripa mine is an experimental field laboratory in central Sweden in which several countries are conducting tests related to nuclear waste disposal. Stripa provides an environment that closely simulates an actual repository and is thus ideal for conducting glass corrosion experiments.

A joint project was initiated in 1982 between the Univesity of Florida (U.F.), Savannah River Laboratory (SRL), and the Swedish Nuclear Fuels Safety Divisiun of the Nuclear Fuel Supply Company (SKBF/KBS). One of the objectives of this project is to evaluate the corrosive behavior of selected SRL glasses in a realistic repository environment. A second objective is to develnp a characterization methodology for comparing field data with laboratory data. It is usually not possible to analyze solutions from field experiments, and to calculate leach rates based on these analyses. Therefore, surface analyses will have to provide the primary 
evaluation method for comparing field- and laboratory-corroded specimens. A third objective is to assess corrosion mechanisms, and to correlate the mechanisms observed in laboratory-corroded versus field-corroded specimens. This last objective is essential because predictive models require a thorough understanding of the mechanisms of corrosion.

Test methods and results from a similar experiment involving Swedish glasses were reported at the Berlin meeting in 19821,2 and updated at this present conference. 3

\section{EXPER IMENTAL}

Three glass compositions: $S R L+29.8 \%$ TDS waste (GIass A); SRL $165+29.8 \%$ TDS waste (Glass B); and SRL $131+35 \%$ TDS waste (Glass C) were prepared by SRL (Table I). Two sample configurations were manufactured: 1) mini-cans and 2) pineapple slices. The mini-cans were made by melting glass frit and simulated waste at $1150^{\circ} \mathrm{C}$ for 2 to 6 hours, casting the glass in stainless steel rings $32-\mathrm{mm}$ in diameter and 35-mm-long, annealing for 1 hour at $500^{\circ} \mathrm{C}$, drilling a hole 20-mm through their centers, and polishing both surfaces of each can to a 6-um finish with diamond paste. Pineapple slices were prepared by casting 51-mm-diameter $\times 80-\mathrm{mm}$-long cylinders in molds containing a center carbon post. Sections were then sliced from the cylinders and the center posts were removed. One side of each 5-mm-thick pineapple slice was then polished to 600 grit surface finish. Additional laboratory samples were prepared using the same compositions, and the same melting and casting procedures. 
Each sample was analyzed by optical microscopy (10x) and Fourier Transform Infrared Reflection Spectroscopy (FT-IRRS) prior to burial. The locations of these analyses were recorded to analyze the identical areas on the samples after retrieval.

The pineapple slices, mini-cans, granite slices, compacted bentonite slices, and various metal coupons were assembled (at the University of Lule, Sweden) to provide a wide range of glass/ repository material interfaces. A typical pineapple slice assembly is shown (Figure 1) both before and after 1-month burial at $90^{\circ} \mathrm{C}$.

Seven pineapple slice assemblies (different sample stacking sequences) and five mini-can assemblies (same sample stacking sequence) were buried in 3-meter deep boreholes at the 345-meter level in the Stripa mine, as indicated in Figure 2 . Heater rods were placed in the center 20 -mm holes on samples to be maintained at $90^{\circ} \mathrm{C}$ (Figure 3 ).

Assemblies are being retrieved at specified intervals over a two-year period. The last assemblies are expected to be removed in early 1985. After removal of the 1-month burial assemblies from the boreholes, they were wrapped in plastic until disassembled and analyzed. Water from the boreholes was analyzed prior to and after the assemblies were rcmoved. Water cuiliposition and $\mathrm{pH}$ prior to burial is given in Table II.

The $\mathrm{pH}$ changed by less than 1 unit in the borehole from which the 1 -month, $90^{\circ} \mathrm{C}$ mini-can was removed. Measured flow rates through similar holes located elsewhere in the mine were approximately 
1 liter/yr. The glass surface area to solution volume ratios $(\mathrm{SA} / \mathrm{V})$ in the 1 -month, $90^{\circ} \mathrm{C}$ holes were calculated to be about $0.6 \mathrm{~cm}^{-1}$ for the pineapple slice assembly and $0.06 \mathrm{~cm}^{-1}$ for the mini-can assembly.

To date, 1-month and 3-month assemblies have been retrieved, but only the 1-month samples have been analyzed. Post-burial procedures consist of careful disassembly, soaking in deionized water for no more than $5 \mathrm{~min}$. to remove excess bentonite (if present), and $5 \mathrm{~min}$. cleaning in acetone twice. The samples are air-dried and placed in a desiccator until analyzed. All samples are analyzed with FT-IRRS and optical microscopy before and after burial, and selected samples are analyzed with SEM-EDS, SIMS, and AES-IM.

\section{RESULTS AND DISCUSSION}

When the assemblies are removed from the bore holes there is a thin (about $5 \mathrm{~mm}$ ) coating of bentonite over their outer surfaces. Apparently, the compacted bentonite swells during burial and is extruded between the sides of the granite boreholes and the surfaces of the assemblies. In some instances bentonite instrusion was observed between the pineapple slices. Accelerated attack was usually found on the yldss surfaces exposed to compacted bentonite slices, or where bentonite had intruded between two other samples.

Cracks were observed on many of the pineapple slices during disassembly. Two possible causes for the cracks are: (1) pressure due to the swelling of the bentonite during burial, which produced 
a bending moment on the glass samples and (2) large forces required to extract the assemblies from the boreholes (also due to the swelling of the bentonite), which also produced a bending moment on the glasses.

SEM-EDS analyses of glass A surfaces (pineapple slices) that were buried in contact with various repository materials are shown in Figure 4. A pre-burial surface analysis is also presented for the purpose of comparison. Polish scratches are visible on the pre-burial surface. In general, the extent of surface deterioration and compositional changes appear to be small on all of the samples with the exception of those buried in contact with the bentonite. The small variations in surface composition are probably due to the fact that the layers that have formed on the various surfaces are much thinner than the depth of EDS analys is (i.e., 1-2 $\mu \mathrm{m})$. Thus, the contribution to the EDS spectra from the underlying bulk glass is much larger than that due to the surface films.

rigure 5 shows another area of the glass that was in contact with bentonite. This region contained some $\mathrm{Fe}-\mathrm{Ni}$ rich crystals produced during glass fabrication prior to burial. The most significant feature observed is the accelerated corrosion at the crystal/glass interfaces. The majority of the samples used in the investigation did not contain any visible crystals.

Auger spectra are presented in Figure 6 for glass $A$ surfaces buried in contact with bentonite and in contact with another glass 
A sample. The peak heights for the various elements are normalized to the pre-burial glass in Table III. The concentration of $\mathrm{Al}, \mathrm{Mg}$, and $\mathrm{Fe}$ are all enhanced at the surface after burial. $\mathrm{Al}$ and $\mathrm{Fe}$ appear to be slightly more enhanced on the surface buried in contact with the bentonite, which is consistent with what has been found in laboratory studies. 4

Optical mircographs and corresponding FT-IRRS spectra from the same areas are shown in Figure 7 . These data suggest very little surface alteration on the glass buried in contact with glass, or buried in contact with granite or lead. The most significant alteration occurred on surfaces buried in contact with bentonite. In one area on the glass sample in contact with granite, there was relatively severe deterioration, but bentonite intrusion was found in this area (Figure $7 b$ ). The accelerated attack observed on the glass and partially devitrified glass in contact with bentonite (Figures $7 e, f$ ) is consistent with the SEM-EDS analysis. Using these depths of analyses as guidelines, the depths of surface alteration for glasses in corltact with various repository materials are:

$\begin{array}{ll}\text { Glass/Glass } & <00.5 \mu \mathrm{m} \\ \text { Glass/Granite } & <<0.5 \mu \mathrm{m} \\ \text { Glass/Stainless Steel } & <0.5 \mu \mathrm{m} \\ \text { Glass/Lead } & <<0.5 \mu \mathrm{m} \\ \text { Glass/Bentonite } & >0.5 \mu \mathrm{m},<2 \mu \mathrm{m}\end{array}$


Table IV presents the solution analys is for Glass A corroded in the laboratory at $90^{\circ} \mathrm{C}$ for 28 days at two different SA/V ratios, $0.1 \mathrm{~cm}^{-1}$ and $0.03 \mathrm{~cm}^{-1}$. These data show that the extent of leaching increases as $S A / V$ decreases, due primarily to concentration effects. The $S A / V$ values calculated for the in situ repository test $\left(0.6\right.$ and $0.06 \mathrm{~cm}^{-1}$ ) were close to the laboratory values, but the extent of corrosion determined from the FT-IRRS analysis indicated that the in situ glasses performed better than the laboratory samples (Figure 8 ). The reason for this is thought to be due to the much larger "effective SA/V" existing between the interfaces $\left(>100 \mathrm{~cm}^{-1}\right)$ which significantly reduces glass corrosion due to concentration (saturation) effects.

The same general trends observed in the laboratory for durability of Glasses $B$ and $C$ were also observed for the field tested compositions. For example, Glass B contains a new frit, type 165, that is more durable than Glass A containing frit 131 . This is not only observed in laboratory tests, but has now been conflrmed using FT-IRRS analys is for in situ tests. Also, the most durable composition studied for the burial glasses was determined by FT-IRRS to be Glass $C$, a glass of high waste loading. The beneficial effects of adding waste to nuclear glass systems is consistent with previous studies. 2,5 


\section{SUMMARY AND CONCLUSIONS}

Although this project is still in the initial stages, a methodology has been established for analyzing the post-burial samples. The following is a summary of our initial findings on the interactions of Savannah River Plant (SRP) waste glasses buried for one month at $90^{\circ} \mathrm{C}$ in the Swedish granite mine.

- In general, very little surface deterioration or compositional changes were observed for glass-glass, glass-metal or glass-granite interactions.

- Glass attack was accelerated for all three glass compositions buried in contact with bentonite and for glasses containing crystalline products. In the latter case, accelerated corrosion occurred most appreciably at glass/crystal interfaces in the presence of bentonite.

- Outer surfaces of post-burial samples were most often enriched in $\mathrm{Al}, \mathrm{Mg}$, and $\mathrm{Fe}$ compared to preburial samples.

- The improved durability of SRP waste glass using a new frit (SRL 165) composition and the beneficial effect of higher waste-loaded glasses have already been observed in the laboratory. These effects were also observed in the burial glasses using FT-IRRS.

- The burial glasses exhibited better corrosion resistance than glasses studied in the laboratory. This is attributed to the beneficial effect of a higher $S A / V$ ratio that will exist in many repository scenarios. 
- Based on FT-IRRS analysis, the relative corrosion ranking of the three glasses (in order of decreasing durability) is Glass C> Glass $B>$ Glass A.

\section{ACKNOWLEDGEMENTS}

This work was supported primarily by SRL. KBS provided the boreholes and costs of burial at Stripa and DOE provided support for SEM-EDS analysis. The contributions of L. L. Hench are appreciated, as well as the Auger analysis provided by P. G. Whitkop.

\section{REFERENCES}

1. L. Werme, L. L. Hench and A. Lodding, "Effect of Overpack Materials on Glass Leaching in Geological Burial," in Scientific Basis for Nuclear Waste Management V., Elsevier Science Publishing Company, Inc., pp. 135-144 (1982).

2. D. E. Clark, C. A. Maurer, A. R. Jurgensen and L. Urwongse, "Effects of Waste Composition and Loading on the Chemical Durability of a Borosilicate Glass," ibid. pp. 1-14, New York, (1982).

3. L. L. Hench, A. Lodding and L. Werme, "Analys is of One Year in Situ Burial of Nuclear Waste Glasses in Stripa." (this book)

4. L. L. Hench, L. Werme and A. Lodding, "Burial Effects on Nuclear Waste Glass," ibid, Reference 1, pp.153-162 (1982).

5. W. D. Rankin and G. G. Wicks, "Chemical Durability of Savannah River Waste Glass as a Function of Waste Loading," Journal of Am. Ceram. Soc., Vol. 6, No. 6, pp. 417-420 (1983). 
TABLE I. SRL Waste Glass Compositions Used in the Stripa Burial

\begin{tabular}{|c|c|c|c|c|c|}
\hline Component & Frit & Waste & $\begin{array}{r}\text { Glass A } \\
(131 / T D S) \\
\end{array}$ & $\begin{array}{c}\text { Glass B } \\
(165 / T D S) \\
\end{array}$ & $\begin{array}{c}\text { G lass C } \\
(35 \% / T D S) \\
\end{array}$ \\
\hline $\mathrm{SiO}_{2}$ & $x$ & & 40.6 & 47.7 & 37.6 \\
\hline $\mathrm{Na}_{2} \mathrm{O}$ & $x$ & & 12.4 & 9.1 & 11.5 \\
\hline $\mathrm{B}_{2} \mathrm{O}_{3}$ & $x$ & & 10.3 & 7.0 & 9.6 \\
\hline $\mathrm{TiO}_{2}$ & $x$ & & 0.7 & --- & 0.7 \\
\hline $\mathrm{Li}_{2} \mathrm{O}$ & $x$ & & 4.0 & 4.9 & 3.7 \\
\hline $\mathrm{MgO}$ & $x$ & & 1.4 & 0.7 & 1.3. \\
\hline $\mathrm{ZeO}_{2}$ & $x$ & & 0.4 & 0.7 & 0.3 \\
\hline $\mathrm{La}_{2} \mathrm{O}_{3}$ & $x$ & & 0.4 & -- & 0.3 \\
\hline $\mathrm{Fe}_{2} \mathrm{O}_{3}$ & $x$ & $x$ & 13.4 & 13.4 & 15.8 \\
\hline $\mathrm{MnO}_{2}$ & & $x$ & 3.9 & 3.9 & 4.5 \\
\hline Zeolite & & $x$ & 2.9 & 2.9 & 3.4 \\
\hline $\mathrm{Al}_{2} \mathrm{O}_{3}$ & & $x$ & 2.7 & 2.7 & 3.2 \\
\hline $\mathrm{NiO}$ & & $x$ & 1.6 & 1.6 & 1.9 \\
\hline $\mathrm{SiO}_{2}$ & & $x$ & 1.2 & 1.2 & 1.4 \\
\hline $\mathrm{CaO}$ & & $x$ & 1.0 & 1.0 & 1.2 \\
\hline $\mathrm{Na}_{2} \mathrm{O}$ & & $x$ & 0.9 & 0.9 & 1.0 \\
\hline Coal & & $x$ & 0.7 . & 0.7 & 0.8 \\
\hline $\mathrm{Na}_{2} \mathrm{SO}_{4}$ & & $x$ & 0.2 & 0.2 & 0.2 \\
\hline $\mathrm{Cs}_{2} \mathrm{CO}_{3}{ }^{\star}$ & & $x$ & 0.1 & 0.1 & 0.2 \\
\hline $\mathrm{SrCO}_{3}{ }^{\star}$ & & $x$ & 0.1 & 0.1 & 0.2 \\
\hline$U_{38^{*}}$ & & $x$ & 1.1 & 1.1 & 1.3 \\
\hline & & & L $\quad 100.1$ & 99.9 & 100.1 \\
\hline
\end{tabular}

Glass A: 29.8 wt \% TDS Waste/70.2\% Frit 131

Glass B: 29.8 wt \% TDS Waste $/ 70.2 \%$ Frit 165

Glass C: $35 \%$ TDS Waste/65\% Frit 131

* TDS Waste was doped with C's, Sr and U. 
TABLE II. Ground Water Composition and pH at Stripa Concentration $\mathrm{mg} / \mathrm{l}$

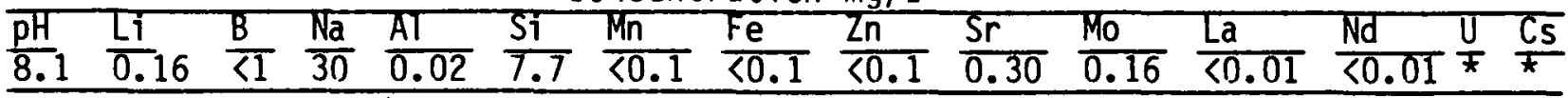

TABLE III. Normalized Auger Data for Glass A Surfaces that were in Contact with Various Interfaces During Burial for 1 Month at. $90^{\circ} \mathrm{C}$

\begin{tabular}{llllll}
\hline Sample & Si & AI & Mg & Ti & Fe \\
\hline $\begin{array}{llllll}\text { Pre Burial } \\
\text { Surface }\end{array}$ & 1 & 1 & 1 & 1 & \\
Glass/Glass & 0.69 & 2.0 & 3.8 & 0.76 & 2.1 \\
Glass/Bentonite & 0.61 & 2.8 & 3.7 & 0.84 & 2.2 \\
\hline
\end{tabular}

TABLE 1V. Solution Analysis for Glass A Corroded in the Laboratory Deionized Water for $28 \mathrm{~d}$ at $90^{\circ} \mathrm{C}$

\begin{tabular}{|c|c|c|c|c|c|c|c|c|c|}
\hline \multirow{2}{*}{\multicolumn{10}{|c|}{$\frac{\text { CONCENTRATION }}{\mathrm{Sr}}$}} \\
\hline & & & $B$ & & $\mathrm{Sr}$ & AI & $\mathrm{Fe}$ & & \\
\hline $0.1 \mathrm{~A}$ & & 48.8 & 9.50 & 29.6 & $<0.003$ & 1.95 & 0.30 & 0.183 & 0.031 \\
\hline & & 46.3 & $\underline{8.99}$ & 27.5 & $\leq 0.003$ & 1.95 & 0.35 & 0.195 & 0.033 \\
\hline VALUE & 9.54 & 47.6 & 9.25 & 28.6 & $<0.003$ & 1.95 & 0.33 & 0.189 & 0.032 \\
\hline $0.03 \mathrm{~A}$ & & 21.5 & 3.89 & 12.5 & $<0.003$ & 0.644 & 0.044 & 0.051 & 0.024 \\
\hline & & 28.3 & 4.90 & 14.9 & $<0.003$ & $\underline{1.06}$ & 0.083 & 0.036 & 0.022 \\
\hline VALUE & 9.48 & 24.9 & 4.40 & 13.7 & $<0.003$ & 0.852 & 0.064 & 0.044 & 0.023 \\
\hline
\end{tabular}

*NORMALIZED LEACH RATE $\left(\mathrm{g} / \mathrm{m}^{2}-\mathrm{d}\right)$

\begin{tabular}{lllllllllll}
\hline$S A / V$ & $\begin{array}{l}\text { Total } \\
\left(\mathrm{cm}^{-1}\right)\end{array}$ & $\begin{array}{l}\text { Mass } \\
\text { Loss }\end{array}$ & Si & B & Na & Sr & Al & Fe & Mn & Mg \\
\hline
\end{tabular}

$\begin{array}{llllllllll}0.1 & 0.53 & 0.79 & 1.00 & 1.00 & 0 & 0.48 & 0.01 & 0.02 & -0.1\end{array}$

$\begin{array}{llllllllll}0.03 & 0.71 & 1.38 & 1.58 & 1.60 & 0 & 0.70 & 0.0 & 0.02 & -0.5\end{array}$

Initial $\mathrm{pH}$ of Deionized Water was 5.45

*Calculated using glass composition based on ICP analysis at SRL 


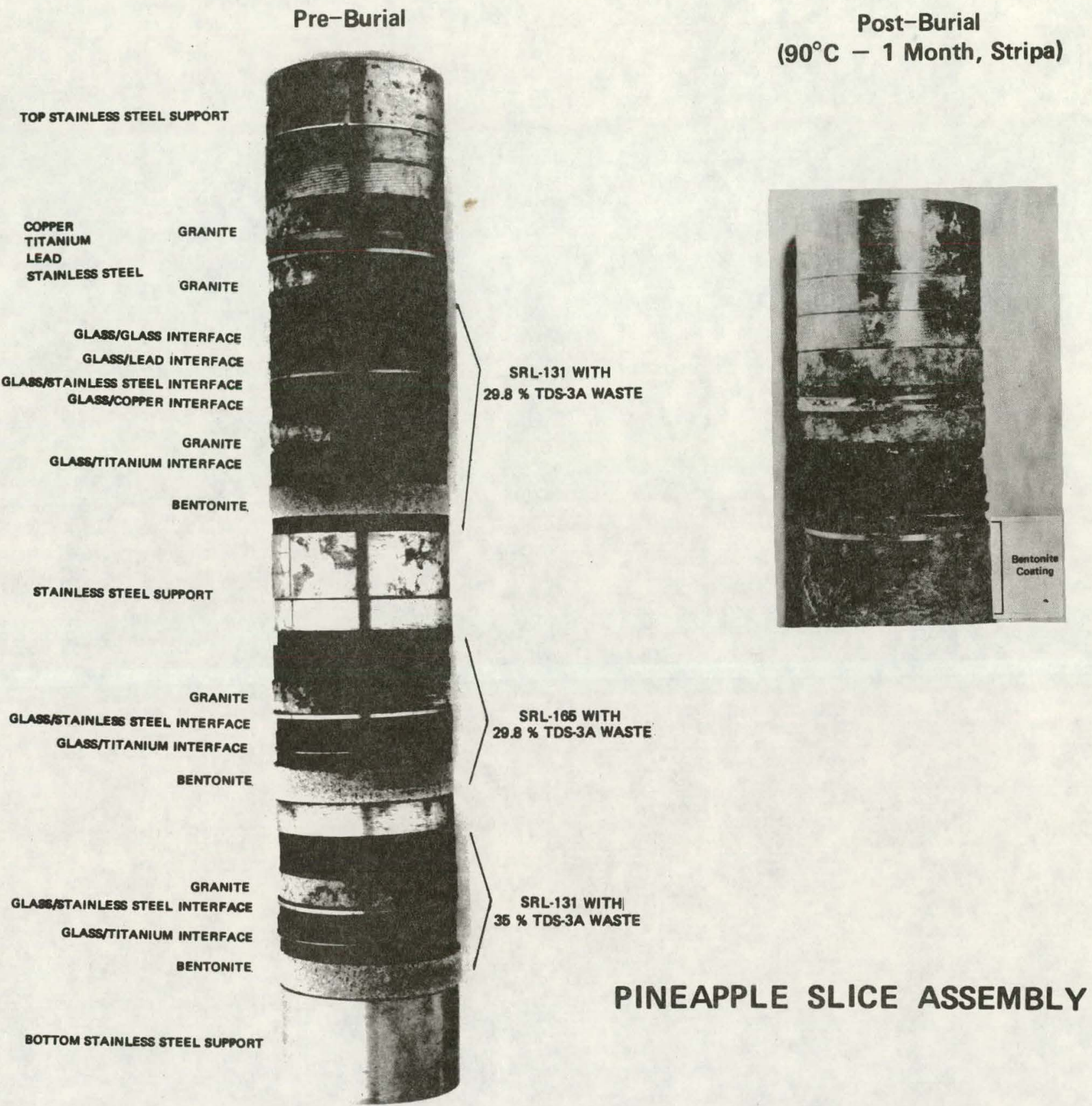

Figure 1. Illustration of the Sample Geometry and the Various Types of Interfaces in the 1 Month, $90^{\circ} \mathrm{C}$ Pineapple S1ice Assembly. Heater rod is inserted into the center of this assembly during burial. 


\section{SCHEMATIC OF BURIAL ASSEMBLY AT STRIPA}
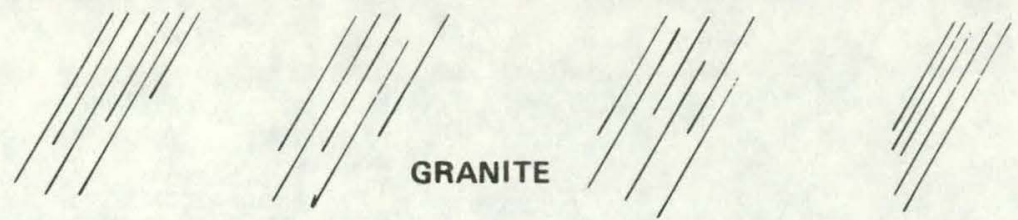

-345 meter level
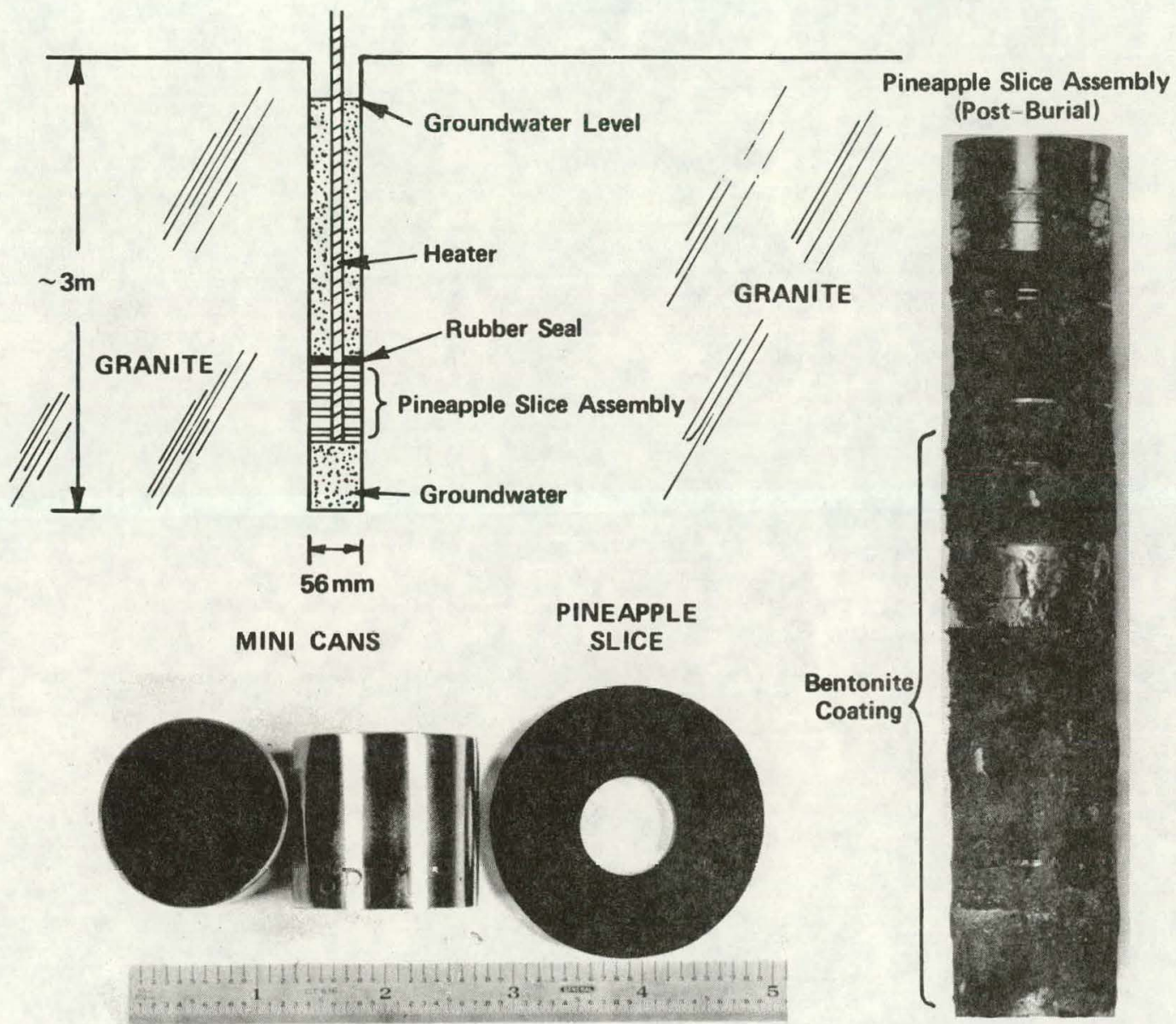

$56 \mathrm{~mm}$

MINI CANS

PINEAPPLE SLICE

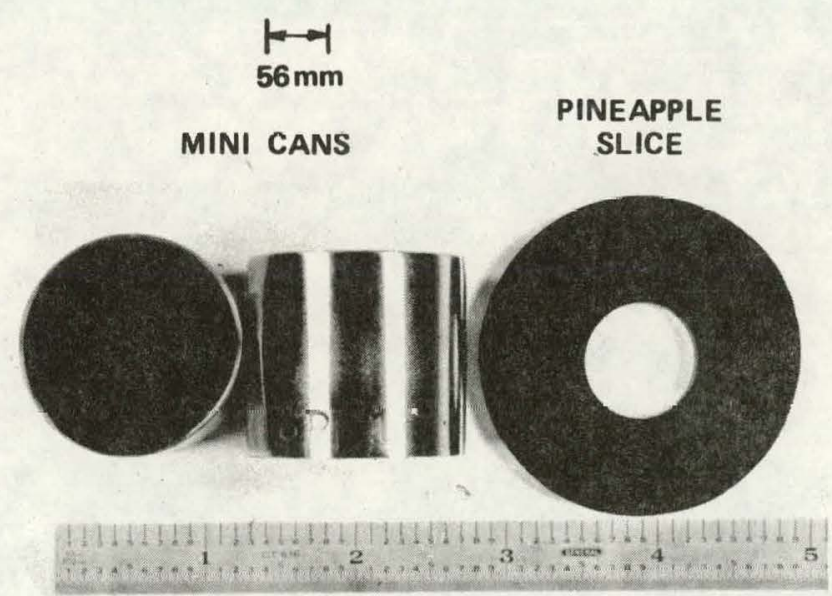
(Post-Burial)
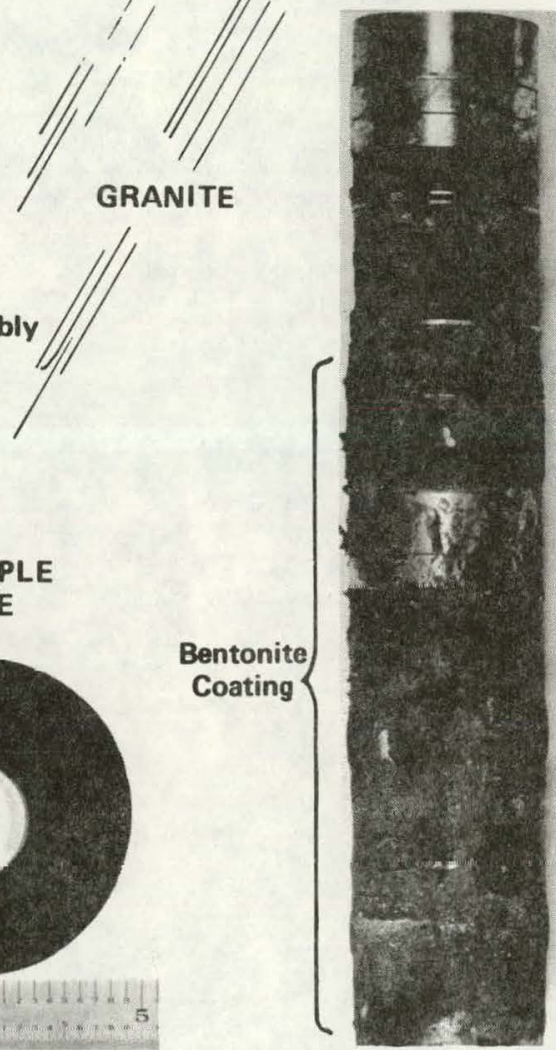

Cross-Section of Sample

(Pre-Burial)

Figure 2. Diagram Illustrating the Position of the Samples in the Stripa Mine During Burial. A pineapple slice and mini-can are also shown, along with a photograph of the 1 month, $90^{\circ} \mathrm{C}$ assembly immediately after removal from the borehole. 


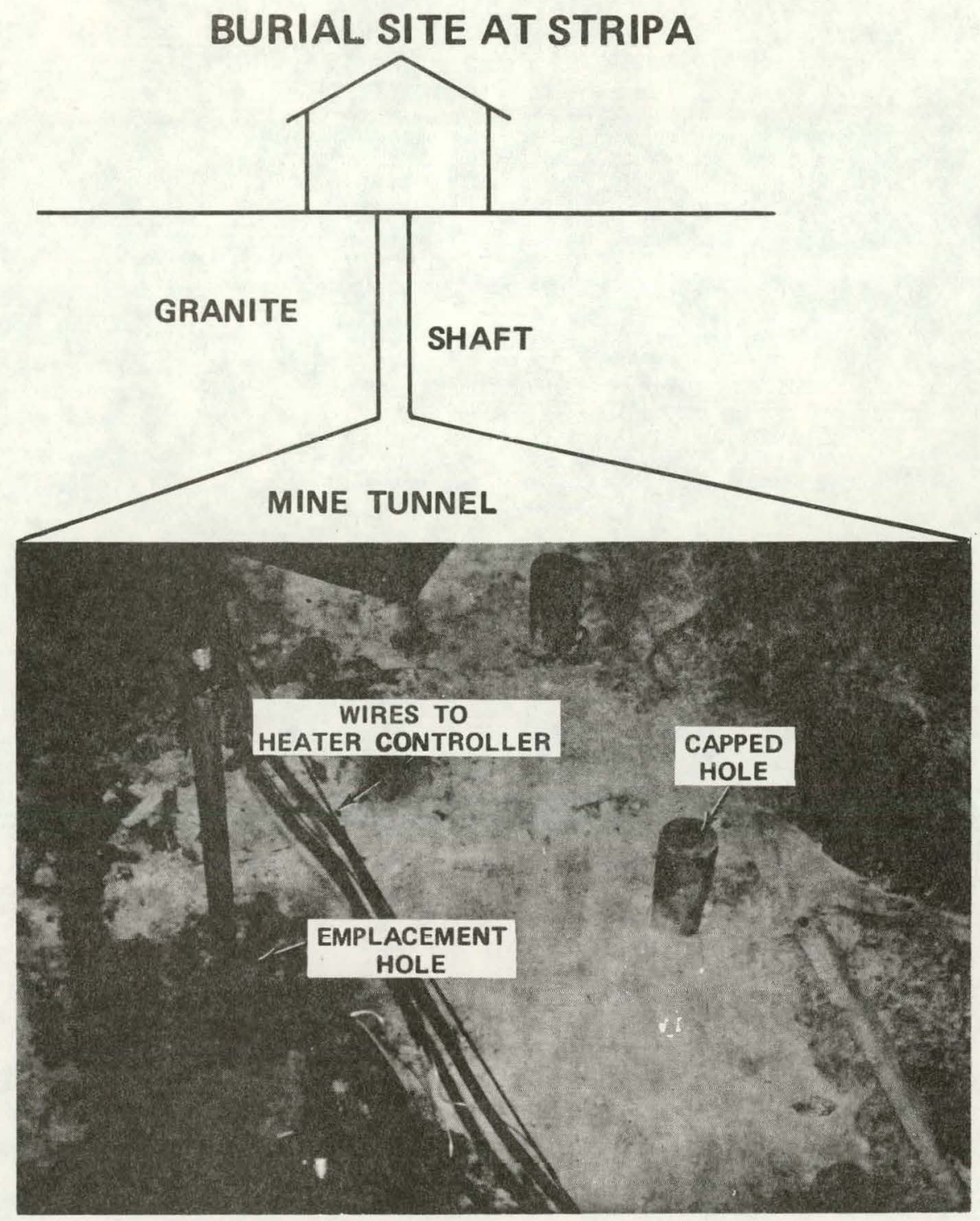

Figure 3. Location Within Stripa Where SRL Samples are Buried. This is about 345 meters below the surface. The holes into which the samples are placed are about 3 meters deep and $56 \mathrm{~mm}$ in diameter. They are filled with water from the mine before the samples are emplaced. The arrow indicates holes into which the 1 month $-90^{\circ} \mathrm{C}$ specimens were placed. Samples are placed in hole to a depth of about 2.5 meters. See Diagram. 

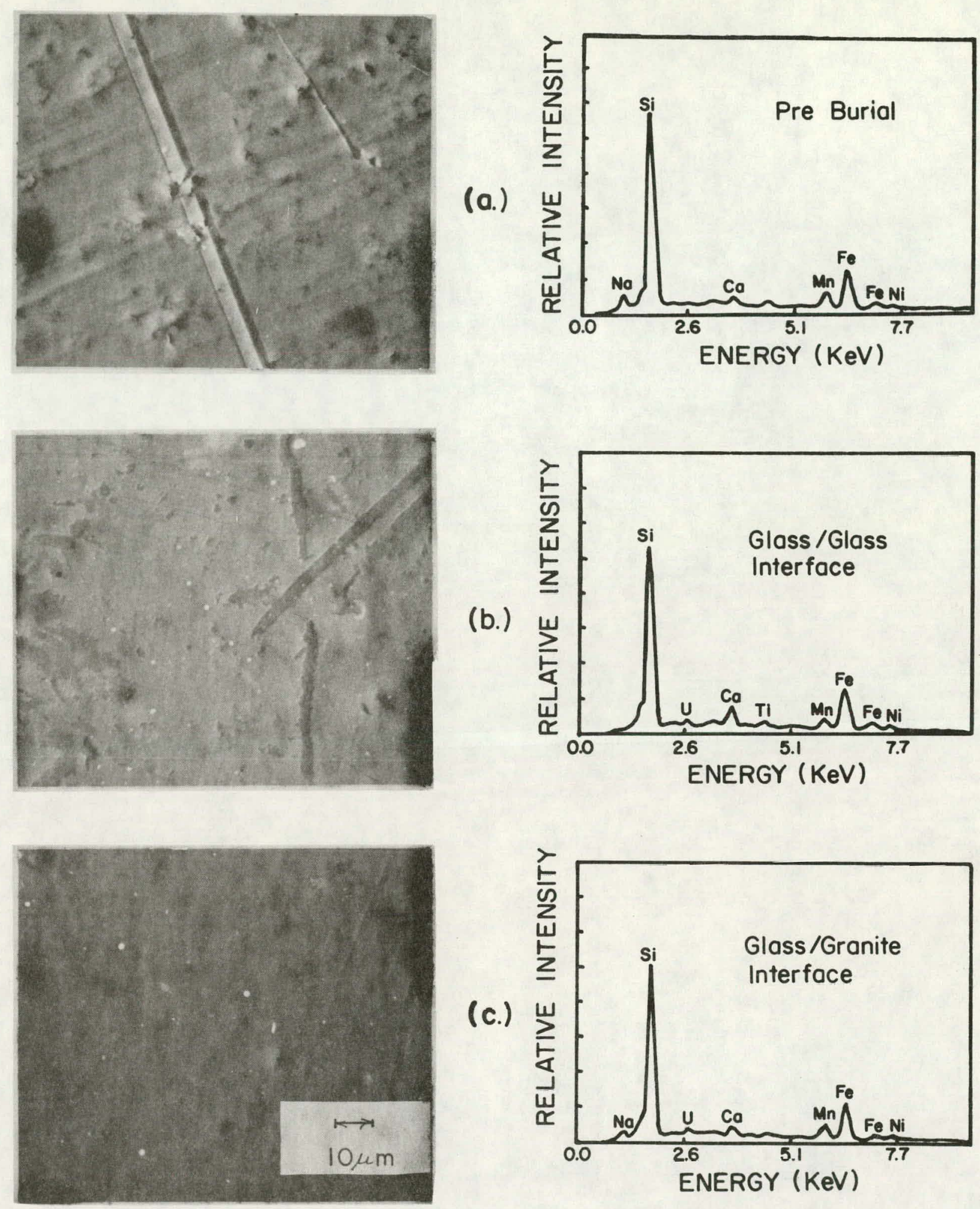

Figure 4. SEM-EDS Analysis of Glass A: a) Pre-Burial Post-Burial for 1 Month at $90^{\circ} \mathrm{C}$; b) Glass/Glass Interface; c) Glass/Granite Interface; d) Glass/Stainless Steel Interface; e) Glass/Lead Interface; and f) Glass/ Bentonite Interface. 

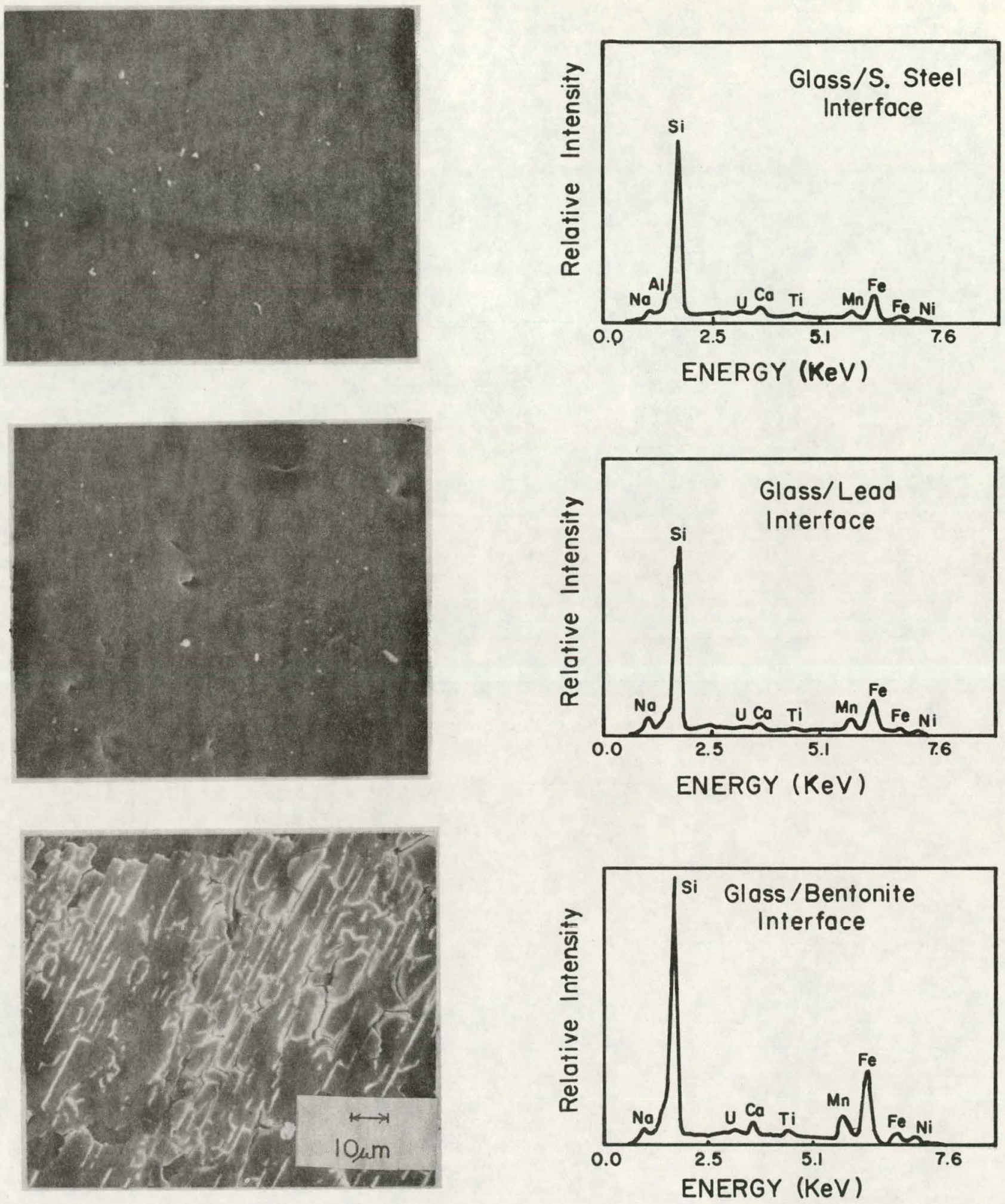

Figure 4 (Continued) 

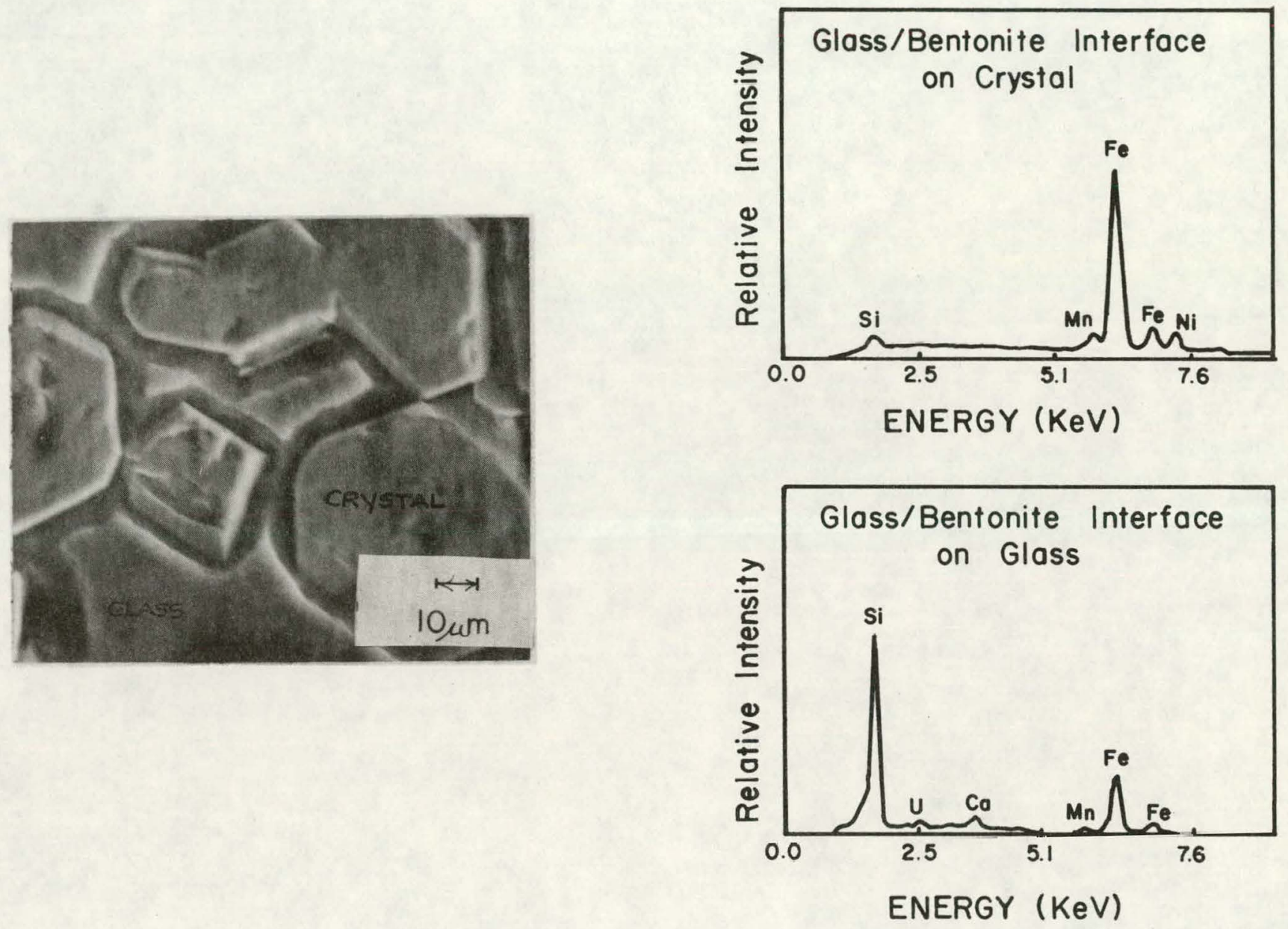

Figure 5. SEM-EDS Analys is of Glass A (Partially Devitrified Area) After Burial for 1 Month at $90^{\circ} \mathrm{C}$ 


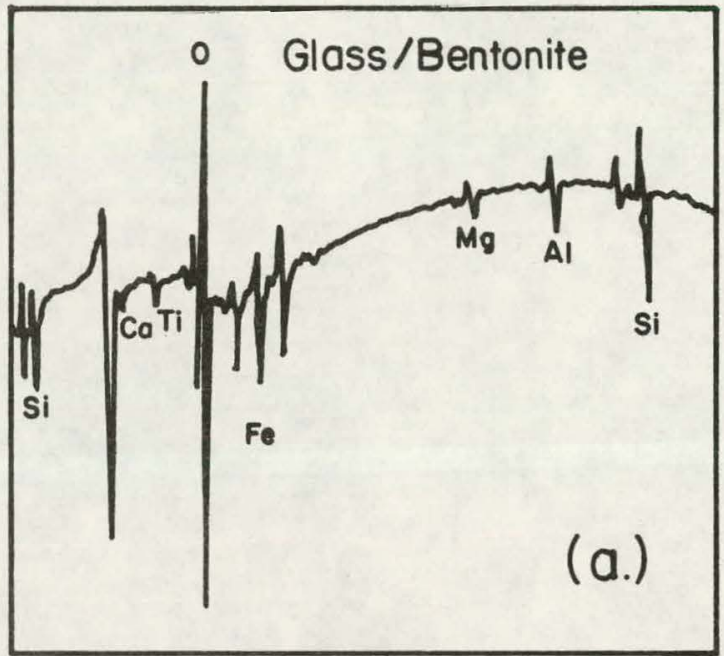

ENERGY

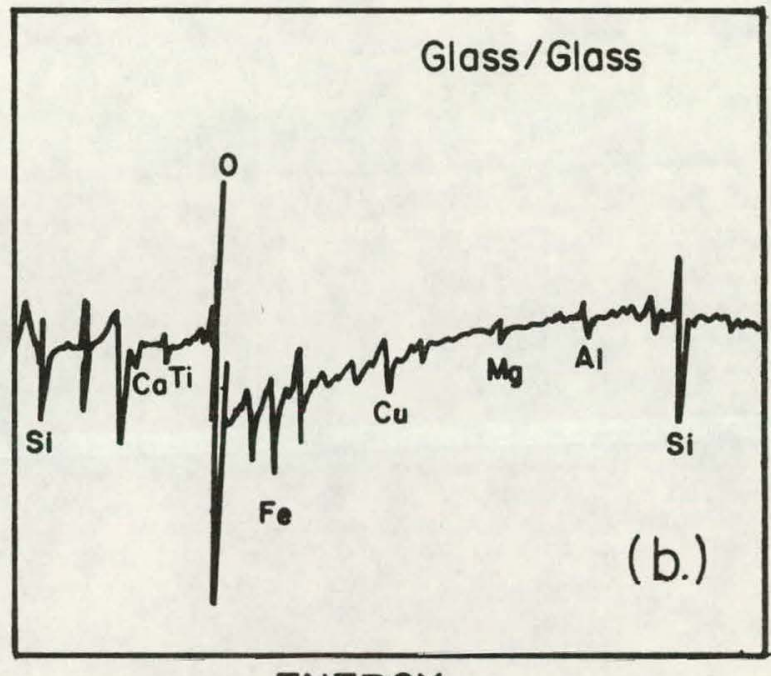

ENERGY

Figure 6. Post-Burial $\left(1 \mathrm{Month}, 90^{\circ} \mathrm{C}\right)$. Auger Spectra of Glass A Surfaces that had been in Contact with Either

a) Bentonite, or b) Another Glass A Surface. 

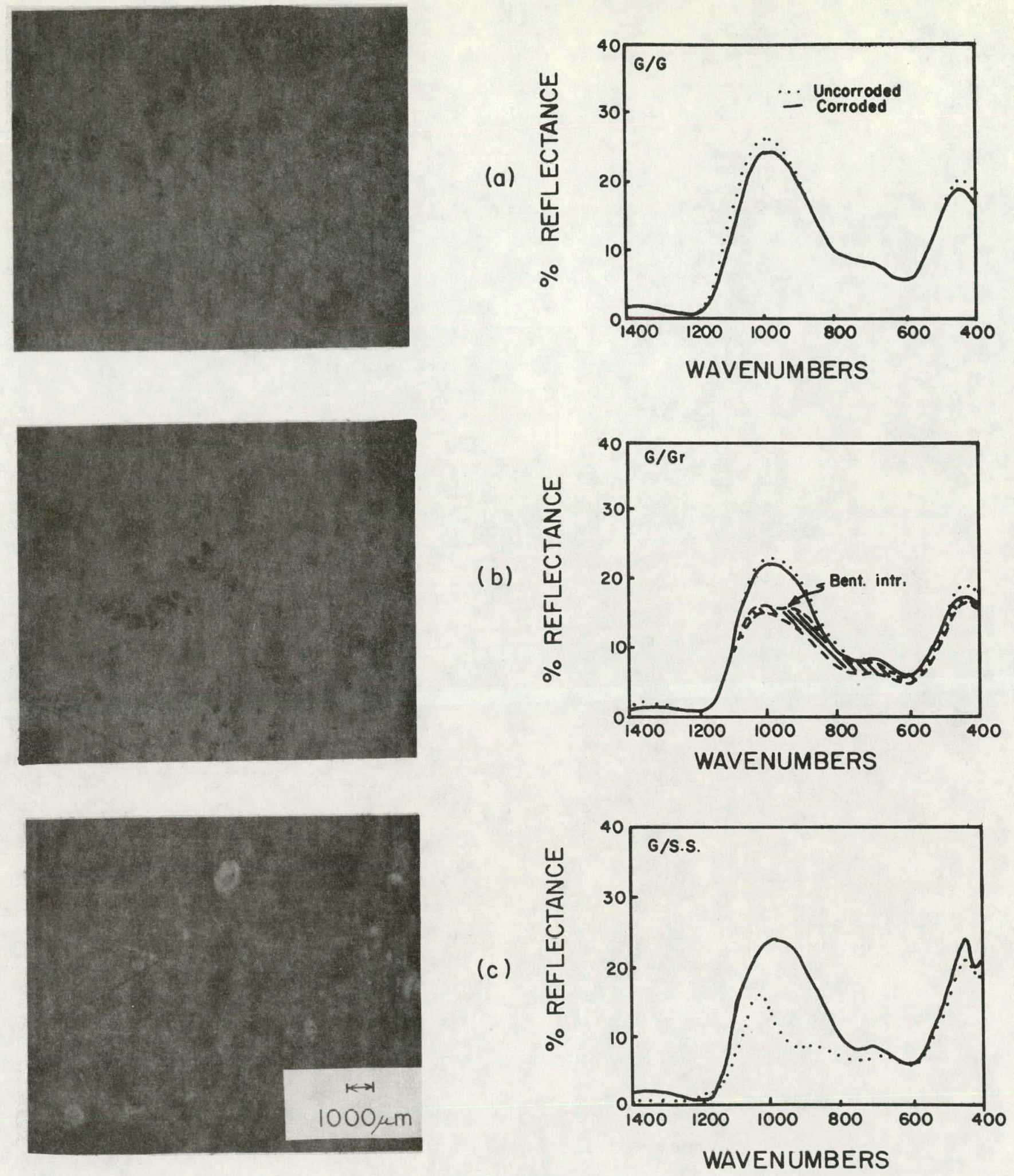

Figure 7. Post-Burial (1 Month, $90^{\circ} \mathrm{C}$ ) Optical Micrographs and FT-IRRS Analys is of Glass A Surfaces that had been in Contact with a) Another Glass A Surface; b) Granite; c) Stainless Steel; d) Lead; e) Bentonite; and f) Partially Devitrified A in Contact with Bentonite. 


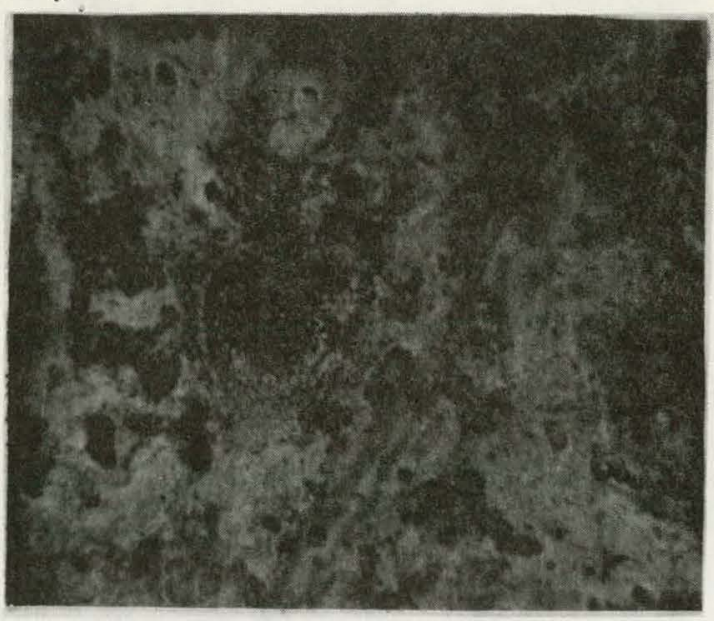

(d)
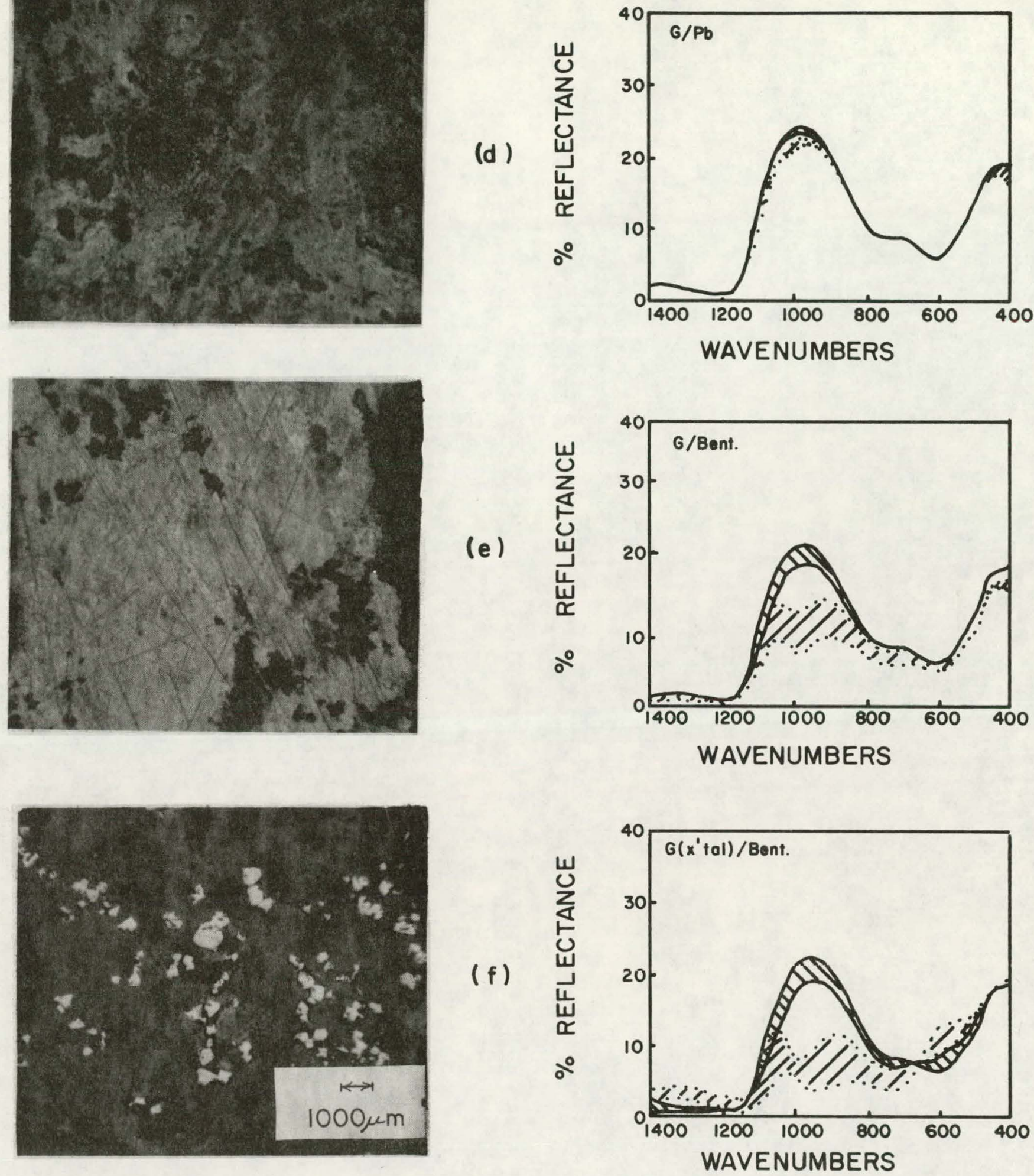

Figure 7 (continued) 

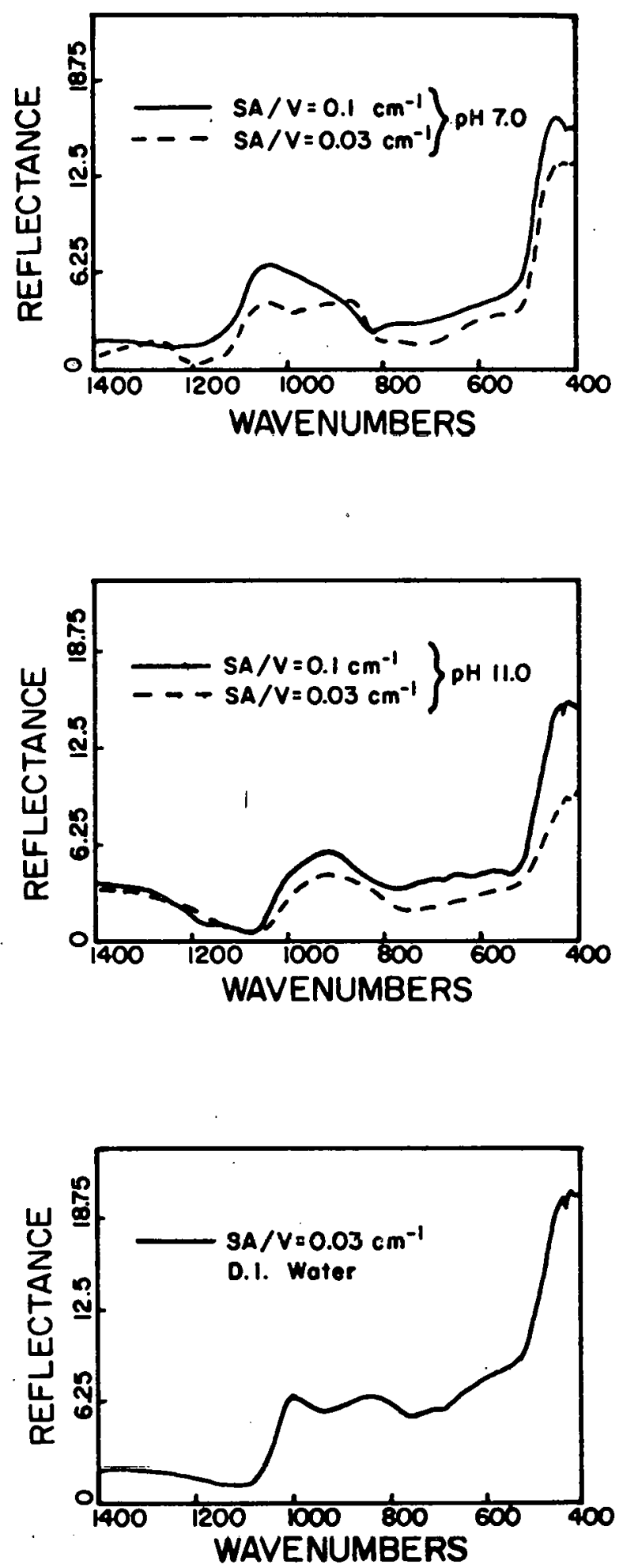

Figure 8. FT-IRRS Analysis of Glass $A$ after Corroding in the Laboratory for $28 \mathrm{~d}$ at $90^{\circ} \mathrm{C} ; \mathrm{SA} / \mathrm{V}=0.1$ and $0.03 \mathrm{~cm}^{-1}$ : a) $\mathrm{pH}=7.0, \mathrm{~b}) \mathrm{pH}=11.0$, and c) Deionized Water. 


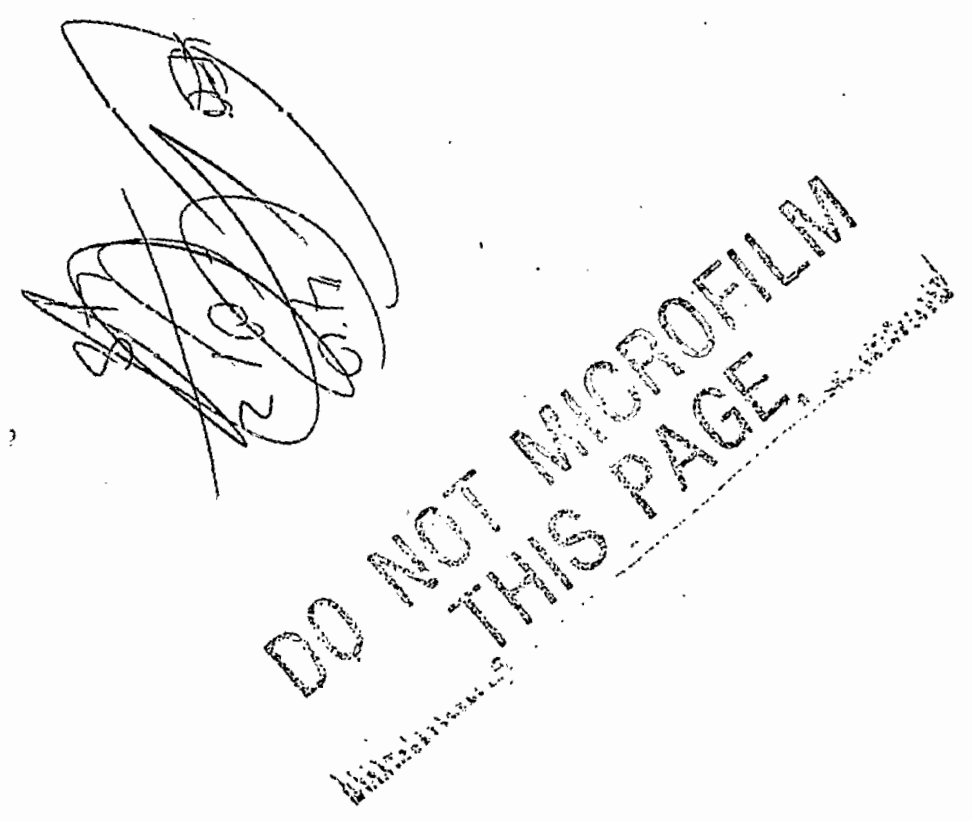

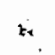

